УДК $821.161 .2-94.09$

Ткаченко В. I. старший викладач кафедри української літератури Вінницького державного педагогічного університету імені Михайла Коцюбинського

\title{
ЛІРИЗМ ЯК ЕЛЕМЕНТ КОРДОЦЕНТРИЗМУ В МЕМУАРИСТИЦІ ГАННИ БАРВІНОК
}

У статті проаналізовано мемуари Ганни Барвінок. Основна увага зосереджена на ліризмі спогадів про Т. Шевченка, П. Куліша, які написані з позицій кордоцентризму, який $є$ ознакою ментальності українського народу.

Ключові слова: мемуари, кордоцентризм, жанр, поезія в прозі, спогади.

В статье проанализировано мемуары Ганны Барвинок. Основное внимание сосредоточено на лиричности воспоминаний о Т. Шевченко, П. Кулише, которые написаны с позиций кордоцентризма, что есть характерной особенностью ментальности украинского народа.

Ключевые слова: мемуары, кордочентризм, жанр, поэзия в прозе, воспоминания.

In this article Hanna Barvinok's memoirs are analysed. The main attention is paid to lyricism of memorials about T.Shevchenko and P.Kulish which are written according to heart philosophy which is a feature of mentality of Ukrainian people.

Key words: memoirs, heart philosophy, genre, poetry in prose, memorials.

Актуальність нашого дослідження обумовлена потребою розширити уявлення сучасного дослідника про мемуарну спадщину Ганни Барвінок, що не досліджувався системно. 
Mema статті: проаналізувати літературні мемуари письменниці, охарактеризувати своєрідність авторського світосприймання.

Художня творчість Ганни Барвінок найчастіше зорієнтована на жіночу тему, в якій авторка виокремлює сирітську долю, поневіряння, страждання. Це обумовлено тим, що ранні твори написані з позицій філософії кордоцентризму, який розвинувся у середині XIX століття і пов’язаний з ім'ям П. Юркевича. Кордоцентризм передбачає важливість почувань-емоцій, тому й мав місце у художній практиці українських романтиків. Поняття серця мало місце у філософській системі Г. Сковороди, Д. Чижевського.

Про художню спадщину Ганни Барвінок писали іï сучасники, зазначаючи, що твори «пройняті ліризмом, цебто поезією почуваннів, якими обгорнуто кожну постать...» [Шаповал 1911:337]. На думку П. Юркевича, «світ... відкривається для глибокого серияя, а звідси вже до осягаючого мислення» [Юркевич 1990:626].

Під таким кутом зору написані не лише прозові твори, а й літературні мемуари, що дозволяють найкраще осмислити справжнє обличчя автора. «Мемуари є не лиме носієм історичної пам'яті, а й свосрідним засобом «духовної наступності поколінь» $i$ показником рівня цчивілізованості суспільства, його свідомого ставлення до свого минулого, та, у такий спосіб, до свого існування взагалі» [Тартаковский 1999:43].

Справжнє обличчя Ганни Барвінок ми можемо дослідити крізь призму спогадів та листів, що $є$ недостатньо вивченими. Тут авторка розкриває себе поступово, з усіма складнощами iї приватного життя з П. Кулішем, у стосунках з близьким і дальнім культурним оточенням. Така «жива» емоція переконує, що ліризм - це складова усього доробку письменниці, яка дає можливість відтворити події, учасником і свідком яких була авторка. Оригінальним жанром прозової творчості Ганни Барвінок, що суголосний з жанром документального нарису, є спогади або спомини. У виданні творів 2001 року їх представлено 7 : «Голосіння по Шевченкові», «Кілька зустрічів 3 М. І. Костомаровим»; «Довічний жаль (Спомин про П. Куліша)»; «Спомини про Марка Вовчка»; 
«Спогади про знаємість Куліша 3 домом Білозерських (Присвячую Дорогій моїй сестрі Н. М. 3. Товаришу моєму вірному)»; «Спомини А. М. Куліш (Ганни Барвінок)»; «Згадка про Т. Г. Шевченка (1847 р.)» [Барвінок 2001].

Унікальним художнім явищем $є$ перший із зазначених творів, виконаний у стильовому ключі народного голосіння за померлим, - «Голосіння по Шевченкові».

Як відомо, голосіння - стародавній український фольклорний жанр, що сягає доісторичних часів. Вважається, що покійник чує того, хто звертається до нього 3 монологом-голосінням, прохаючи пробудитися, просить не гніватись, озватися, пересипаючи мову похвалами, пестливими зверненнями. Зразки такої емоційно-схвильованої мови $є$ у «Голосінні» Ганни Барвінок: «Чого ти так задумався-загадався, наш батьку рідний! яка важка дума обняла твою головоньку? Кому ти уручаєш вдову - Украӥну $і$ діток свойх? Хто їх догляне, хто привітає, як ти, наш голубе? Хто замовить нам тепле і щзире слово, як твоя свята душа нам оповідала?..» [Барвінок 2001:235].

Підсилюючи ліризм i драматичну напругу вислову, письменниця переходить до розгорнутих протиставлень життя і смерті: «Боже!.. Розів ються садочки - а тебе, мій голубе, $і$ не буде! Защебече соловейко, закує зозуля - а тебе, наш жалібнику, і не почуєм...» [Барвінок 2001:235]. Риторичні запитання і звертання персоніфікують душевний біль, безмірність втрати: «3 якої ж сторони тебе, наше сонцее, вітати? їсти й пити не будем - тебе, сирітський наш батеньку, будем виглядати... Хто ж промовить до нас душею, хто тихим своїм словом зжене тугу з нашого серияя?.. Ти у нас був старший од усіх, а як заговориш, то, мов, найменший брат. Річ твоя тиха, а корила собі всю Україну!..» [Барвінок $2001: 235]$.

Після слів про істинну велич поета і невдавану скромність - дивовижної глибини слова про самодостатність, високу самоцінність цієї постаті: «Не треба тобі ні рідних, ні хрещених діток, щзоб одпокутовать тобі містечко на тім світі: ти сам собі спокутував, страждучи по темних братах своїх!.. Не 
оглянулись ми, як ти уже й рушив на Божу дорогу... мов зоря вечірняя покотилася - замаячила - геть, $i$ - згасла!» [Барвінок 2001:235].

Логічний рух почуття веде до думок про гірку особисту долю поета. «I жупана на тебе, як слід, не вложили, шапки з квіткою, як поводиться, не спорядили! бояр, світилок не скликали, всього поӥзда твого красного великого не зібрали. Весілля ти не мав і щастя не знав» [Барвінок 2001:235].

Голосільниця хоче йти вслід за небіжчиком, тож є в «Голосінні...» Ганни Барвінок і традиційне доручення своїй матері - «сонечку моєму, щзо зайщло од мене», і «батьку рідному: нехай виглядають $і$ мене за собою». Пестливі форми звертання, символічні образи «краси світової» - вічно живої природи, в їх народнопісенному варіанті, передають почуття «жалю, розпуки, любові $i$ пошани» [ЛСД 1997:166]: «Як згадаю, щзо твою головоньку весною калина не затінить, сонечко наше тепленьке не пригріє, соловейко не защебече над тобою, горлички, зозульки не прилетять, здаля дівчата веснянок не заспівають, запашними зіллями, м'ятою, васильками, барвінком, могили не вкриють, своїми дівоцькими чистими сльозами ї̈ не зросять... то аж серденько моє мре, в душі холоне!..» [Барвінок 2001:236].

«У голосінні - відбились анімістичні погляди давніх людей на природу, зокрема, віра в життя душі після смерті... Згадки про голосіння дійшли до нас з часів Київської Русі в літописах, житіях, у «Слові о полку Ігоревім» тощо. ... В них виражено ліричні почуття, тугу, часто - й сочіальні мотиви... Украйнські голосіння виконуються речитативом, але з більшою експресивністю ŭ імпровізацією» [УЛЕ 1988:447]. Всі ці риси й бачимо в «Голосінні по Шевченку». Використовували цей жанр, крім письменниці, i Г. Квітка-Основ’яненко, І. Нечуй-Левицький, М. Коцюбинський, В. Стефаник, Марко Черемшина та інші.

Для цього унікального жанру властивий, як і для поезії в прозі, особливий темпоритм: емфатичне піднесення почуття на початку фрази i трагічне зниження в кінці. Це спостерігаємо і у Ганни Барвінок. 
Закінчується «Голосіння по Шевченкові» словами про те, як багато людей заплаче, затужить за поетом: «Скільки дівочих очей умиються по тобі сльозою!.. Поллються вони по всій Украӥні, як почують, що ти, орле наи, покинув гніздо своє, діток свойх, навіки..» [Барвінок 2001:236]. Проте «Голосіння...» - це не стилізація під народну творчість, під один з характерних, усталених іiі жанрів. Це найбільш адекватний вираз емоцій, почуттів самого автора.

Другий спогад про Т. Шевченка зустрічаємо в «Споминах А. М. Куліш (Ганни Барвінок)» [Барвінок 2001:255-290]. Це - продовження споминів письменниці, опублікованих у журналі «Будучність» (Львів, 1909) під заголовком: «Спогади про знаємість Куліша 3 домом Білозерських». Ганна Барвінок згадує конкретні факти знайомства 3 Т. Шевченком. «Куліш згодом (після заручення, 1846 р. - В. Т.) поӥхав у Київ до Шевченка, - пише вона, - та приєднав його бути старшим боярином. Привіз відтіль $і$ сестру Надежду. Вона там була заміжжю... Перед весіллем за три дні приїхав й Шевченко. Сi три дні ми дуже приємно пробавилися. Він маму нашу дуже полюбив. Вона навдивовижу знала добре народні пісні. Се йому, як маслом по серию... Співали ми з ними вкупі: «Ой, зійди, зійди, ти зіронько та вечірняя». Здається, ие його любима пісня».

Загалом у великій українсько-козацькій родині Білозерських: мати, Мотрона Василівна, удова, і дев'ятеро іiі дітей; оточення - сусіди, родичі, знайомі - Т. Шевченко почувався затишно, багато співав і жартував. Така тут була аура. На самому весіллі між Шевченком, гістьми і Кулішем розігралася весела інтермедійна сценка: «По вечері, - згадує Ганна Барвінок, - як од '̈зжали гості, вся публіка й старший боярин Шевченко підійшов прощатися до мами, а потім й до молодих. Та до молодої обернувшись й каже:

- Чи се царівна, чи королівна! Се не царівна, не королівна, а се Мотрони Василівни дочка Олександра.

Звісно у мами при сіх речах й ушки засміялись.

А Куліш поруч стоячи, каже: 
- На чужий коровай очей не поривай, а собі дбай.

Публіку така сцена дуже оживила, розсмішила...

Молода ж тим часом зняла з голови Fleur d'orange i подала на спомин стариому своєму боярину - Шевченкові. Публіка вся була в незвичайному збудженому настрої, бо ци веселого і в украӥнському дусі не бачили весілля... Тарас Шевченко разом виїхав з Віктором Забілою, до його в господу на хутір Кукуріковщину, під Борзною» [Барвінок 2001:274].

В іншому спогаді - «Згадці про Т. Г. Шевченка (1847 р.)» [Барвінок 2001] письменниця ще раз змалює цей епізод зі свого з Кулішем весілля і додасть: «Ти тоді звеличав мене - княгинею $i$ королівною!.. Боже мій! Я $i$ сама се почувала, бо присутність таких двох велетнів (Шевченко і Куліш - В. Т.) і сила розума придала мені дух красоти, возвисила мене, одухотворила красотою свого подуху на мене; як сонще рослину так ти, мій друже, $і$ Куліш оживили $i$ осяяли мене.

Я Тобою пишалася, мій великий Друже! я Тобі спочувала завсігди, і Твою руку своїми палящими устами поцілувала, маючи на меті з’огріти Тебе, як Ти плакав, над своӥми гадками про Украӥну, що вона «Обідрана сиротою по над Дніпром плаче» [...]. I мене Господь уповажив, що я могла хоч цим Тобі виректи мою прихильність до Тебе - Мученику... За що Тобі така доля судилася, Друже мій неоиінений... За те, щуо Ти широкою пеленою увесь світ обняв, своєю правдивою палкою річчю, вабливою правдою, своєю поезією принадною чуткою, як найкраща квітка пахуща...». Тут знову згадує письменниця про весільний вінок, який оддала старшому боярину «на зобачення»: «Як його арештували на Дніпрі, то в чемодані $і$ мій подарунок був» [Барвінок 2001:290]. Отже, у спогадах про Т. Шевченка дослідник літератури може бачити ще одну сторінку в історії генія, адже Ганна Барвінок була живим свідком подій і неупереджено переповіла ряд історій. Тому ці спогади мають високий ступінь достовірності, документальності та ліризму.

У «Споминах А. М. Куліш (Ганни Барвінок)», які складаються 3 підрозділів «II. П. О. Куліш в 1846 році у Петербурзі. Заручини»; III. Весіллє; 
IV. Прощальний дівич-вечір; V. Ми виїхали за границю» йдеться не тільки про історію кохання і одруження О. Білозерської і П. Куліша, розказану нареченою i дружиною, а й про стосунки в родині, про старосвітський побут Білозерських, прогресивні погляди братів, їх близькість до передових суспільних кіл та тощо. Це справді була видатна українська родина, роль якої в суспільному i культурному житті окреслили дослідники, зазначаючи, що «Білозерським треба віддати належне: вони значною мірою причинилися до пожвавлення «українського елементу» в Російській імперї, до відродження здатності украӥнців самоусвідомлювати себе як окрему духовну спільноту» [Куліш 1997:10].

Мемуари Ганни Барвінок - безцінний матеріал для розуміння обставин життя і творчості іï самої, П. Куліша, багатьох українських письменників, культурних і громадських діячів високодуховної епохи українського відродження. Багато деталей в цих спогадах допомагають нам бачити не ікононізовані портрети, а живих людей з їх радощами, болями, осягненнями й помилками, зрозуміти те, як вони любили, творили, мріяли. Для них властива сповідальна манера письма.

Критика нашого часу особливо високо оцінювала «Голосіння по Шевченкові», цей традиційний і завжди по-новому емоційно-вражаючий жанр. «Своєю стилістикою, асоціятивним способом вираження думок, безпосереднім постійним зверненням до поета, ніби він живий, власне, всією образною мовою «Голосіння» 1861 року перегукується $з$ одним із останніх писань Ганни Барвінок, яке в 1911-1912 роках друкувалося тричі, більшості літераторів $i$ читачів знайоме під назвою «Спомин про стариого боярина Тараса Шевченка на весіллі Пантелія Куліша і Олександри Куліш в 1847 р.» [Барвінок 2001:484]. Цей високопоетичний, пройнятий щирістю етюд, що написаний як спомин до 50-літніх роковин поетової смерті, іноді називають віршем у прозі. Воднораз його можна назвати і спогадом, і сповіддю, і славою, і молитвою. Цей твір народився в уяві Ганни Барвінок за кілька місяців до того, як і вона одійшла у потойбічність. Ніби відчуваючи це, вона звертається до поета: «Прощцавай, 
дорогий друже, пиха нама і всесвітняя; тай мене в незабарі сподівайся на одвідини. Знову поруч станем. Чи познаєш!? Може знов мене, друже незабутий, «королівною, княгинею своєю» звеличаєш?» [Барвінок 2001:484-485].

Документальні відомості разом 3 ліричними спогадами Ганни Барвінок i дають можливість зрозуміти, звідки йшла у письменниці ії глибока любов до рідної мови, пісні, історії, культури, їх розуміння й відчуття, іï органічний патріотизм. Ці речі були в родині просто сакральними.

Мемуари Ганни Барвінок - зокрема ті, де йдеться про Т. Шевченка, П. Куліша, родинні справи, одруження - не мають чіткого хронологічного, щоденниково-документального характеру. Це - емоційні враження, белетризовані описи i сцени, згадки про пережиті почуття. Їм властива повторюваність, розірваність логічного зв'язку і заміна його емоційними сплесками, часова зміщеність, наскрізно піднесена мова (передача наростаючої сили почуття через риторичні запитання й вигуки, емфатичні порівняння й епітети). Вони виступають засобом самоідентифікації особистості письменниці, підведення певних життєвих підсумків у власній історії, та у стосунках із Т. Шевченком і П. Кулішем.

\section{БІБЛІОГРАФІЯ}

Барвінок 1861 - Барвінок Г. Воспоминания о Шевченке; его смерть и погребение. Голосіння українок // Основа. - 1861. - № 3. - С. 16-17.

Барвінок 2001 - Ганна Барвінок: Збірник до 170-річчя від дня народження (Ред. В. Шендеровський, уклад. В. Яцюк). - К. : Рада, 2001. - 556 с.

ЛСД 1997 - Літературознавчий словник-довідник / Р. Гром'як, Ю. Ковалів та ін. - К. : ВЦ «Академія», 1997. - 752 с.

Куліш 1997 - Пантелеймон Куліш. Листи до М. Д. Білозерського./ Упор., вступ. стаття і комент. О. Федорука. - Львів - Нью-Йорк : В-во «М. П. Коць». 1997. -224 c.

Тартаковский 1999 - Тартаковский А. Мемуары как феномен культуры // Вопросы литературы. - 1999. - № 1. - С. 35-55. 
УЛЕ 1988 - Українська літературна енциклопедія: В п’яти томах (Редакційна колегія: І. Дзеверін). - К. : Голов. ред. УРЕ. - 1988. - Т. 1. - С. 129.

Шаповал 1911 - Шаповал О. Ганна Барвінок. Кілька слів 3 нагоди ювілею // Українська хата. - 1911. - № 5-6. - С. 334-338.

Шевченко 1985 - Шевченко Т. Твори: В 5-ти т. - Т. 5 / Приміт. В. Бородіна. - К. : Дніпро, 1985. - 625 с.

Юркевич 1990 - Юркевич П. Философские призведения. - М. : Правда, 1990. $-672 \mathrm{c}$. 